\title{
BOEKBESPREKING: \\ Traditional Jingdezhen wares from contemporary kilns
}

Bij het verzamelen van Chinees porselein gaat bij veel verzamelaars de bepaling van ouderdom van de stukken boven de eigenlijke schoonheid ervan. Deskundigen kunnen die ouderdom bepalen. Telkens lijkt zulk connaisseurschap iets van een zeldzaam hoge status, vaak voorbehouden aan handelaren, medewerkers van veilingbedrijven, welbelezen verzamelaars en medewerkers van musea. Authenticiteit wordt door hen vastgesteld met behulp van vaak moeilijk tot nauwelijks te omschrijven fenomenen aan het object. De kennis word in het algemeen opgedaan uit Westerse literatuur en van objecten die zich aan deze kant van de wereldbol bevinden. Zelden gaat men zelf naar China om daar te leren van nog bestaande productieprocessen of door het raadplegen van Chinese vakliteratuur. Het is echter van groot belang te begrijpen op welke wijze porselein en de decoratie daarop is vervaardigd om te zien hoe een stuk moet worden beoordeeld. Het is tevens noodzakelijk te weten wat er momenteel nog wordt gemaakt in China en hoe dat in verhouding staat tot wat er in het verleden werd gemaakt.

Onlangs verscheen een publicatie in de Chinese vakliteratuur die helder aangeeft wat voor een topkwaliteit nog altijd kan worden gemaakt in China: Traditional Jingdezhen wares from contemporary kilns. De studie verscheen bij een gelijknamige tentoonstelling in het University Museum and Art Gallery of the University of Hong Kong (2-4 tot 5-7-2009). Het boek volgt de indeling van de tentoonstelling nagenoeg op de voet. Samen met de veelheid aan technische aspecten die op bescheiden wijze in de tentoonstelling werden getoond, is deze mooie publicatie een belangrijke bron voor de kennis van de vervaardiging van porselein.

De tentoonstelling toonde het werk van twee keramisten van formaat, Jiang Xunqing en Huang Yunpeng die beiden in Jingdezhen hun bedrijf hebben. Zij imiteerden op meesterlijke wijze stukken porselein uit openbare en particuliere collecties of maakten vrij werk in de stijl van de laatste twee dynastieën. Jiang Xunqing is voornamelijk aan het woord in de publicatie en vertelt de lezer hoe hij, als meester in het vak, zijn leerling zou onderwijzen. Zorgvuldig wordt ingegaan op de houding die de leerling dient aan te nemen ten opzichte van zijn meester, en welke schildertechnieken, hulpmiddelen en materialen nodig zijn voor de vervaardiging van de decoratie op porselein. Het vervaardigen van de objecten zelf wordt buiten beschouwing gelaten omdat dat veelal door anderen wordt verricht. De leerling moet ieder onderdeel van de techniek van decoreren eerst volledig onder de knie hebben voordat hij verder kan gaan naar een volgend onderdeel van het gecompliceerde ambacht. Een leerproces dat vele jaren duurt, zeker voordat men zich mogelijk 'meester' zou kunnen gaan noemen. De finesses van de technieken zijn nauwelijks in woorden te beschrijven, voorzover dat al wenselijk zou zijn omdat ze vaak de 'geheime' kneepjes van het vak zijn. Die worden door-

gegeven van vader op zoon en bij het ontbreken daarvan aan de favoriete 

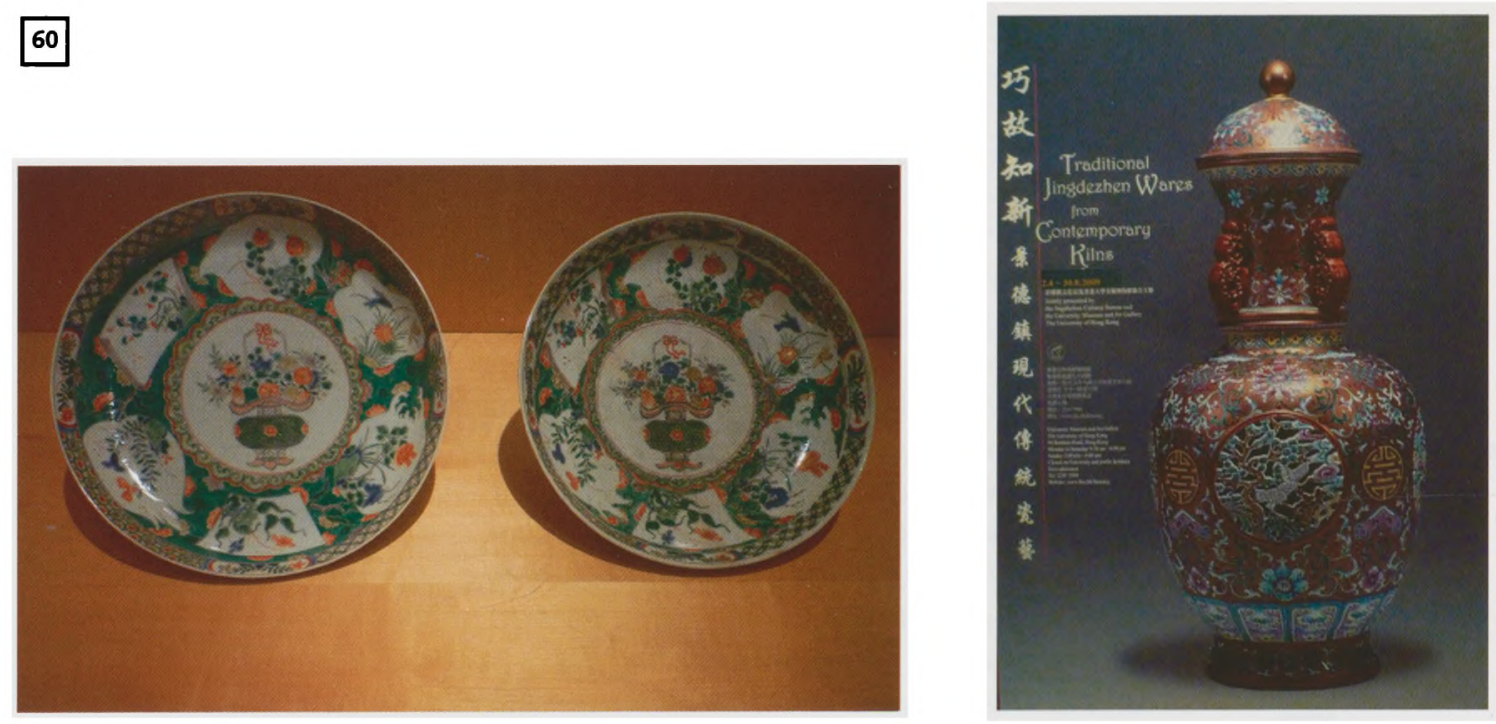

Afbeelding 1

Twee borden waarvan er eén is vervaardigd voor de tentoonstelling en de andere van historische afkomst is.

Afbeelding 2 Affiche voor de tentoonstelling in Hong Kong.

leerling. Echter nooit aan een dochter, dus als de eerste twee opvolgers niet ter beschikking zijn, zullen de geheimen van de techniek met de meester in het graf verdwijnen.

Het boek voorziet in de uitleg van een belangrijk deel van de basistechnieken die geïllustreerd worden met duidelijke kleurenafbeeldingen van de kleurstoffen (keramische oxides met hun Chinese benamingen). Stap voor stap wordt zorgvuldig verteld hoe de moeizame opbouw is van fencai of falancai decoraties (famille rose-kleuren of dik opgebrachte emailkleuren). Het is een unieke bron voor het begrijpen van deze uiterst ingewikkelde en tijdrovende kunstvorm. Naast de techniek wordt ook aandacht besteed aan het kwalitatief selecteren van de resultaten van de gereed zijnde stukken. Eén imperfectie in het werk van één van de vele medewerkers die werkzaam zijn aan ieder stuk kan al leiden tot falen van het eindproduct. Zo is, aldus de schrijver, het succes van een topstuk louter te danken aan het doelbewust samenwerken van àlle medewerkers van de gehele werkplaats.

Het meest omvangrijke deel van het boek is de catalogus van de collectie die is samengesteld uit het werk van de beide keramisten. Helaas zijn hier niet alle teksten in twee talen: de basisbeschrijvingen zijn beschikbaar in het Engels maar de toelichtingen zijn telkens onvertaald gebleven. Voor alle behandelde objecten geldt dat ze zijn vervaardigd met een uiterste vorm van perfectie zonder hiëratisch (streng, star, emotieloos) te worden. Indien deze stukken op de vrije markt zouden komen, zouden ze makkelijk door kunnen gaan voor historische stukken, afkomstig uit onverwachte particuliere bronnen, verborgen gedurende de vele oorlogen en voor de politieke maatregelen die China sedert het afzetten van de laatste Mandsjoe-keizer heeft gekend. ${ }^{1}$

Mogelijk geldt dit in mindere mate voor het werk uit de ovens van de kunstenaar Huang, dat voor een belangrijk deel uit onderglazuur blauw bestaat. Ook hij wil slechts voorbeeldgetrouw het mooiste maken op zijn gebied zonder voor vervalser door te gaan. Het adembenemende porselein met de fencai-decoraties is in het algemeen vervaardigd door zijn collega en volgens de 'meester' vooral gemaakt voor een kleine schare van verzamelaars van moderne kopieën. 
Wat niet in het boek staat maar wel in Hong Kong werd getoond, was een paar (naar aan te nemen) historische stukken met daarnaast door Jiang vervaardigde imitaties (zoals hij deze stukken zelf noemt). Wetende hoeveel kleine verschillen zich reeds in oude stukken voordoen, was het nauwelijks te zien welke het origineel en welke de imitatie was, ware het niet dat dat gelukkig op tekstbordjes werd vermeld.

Het niveau van deze vergelijking toont aan dat er een ononderbroken traditie van vervaardigen van dit porselein moet hebben bestaan in China. De Nederlandse sinoloog en schrijver Henri Borel memoreerde in 1922 al dat, indien de fabrieken in Jingdezhen ineens zouden stoppen met het produceren van kopieën, er spoedig geen 'oud Ming' of 'Cheng-lung' meer verkrijgbaar zou zijn in de wereld. ${ }^{2}$ Hij zou wel eens gelijk kunnen hebben met deze uitspraak. Er is echter nog geen academisch museum ter wereld mij bekend dat het heeft aangedurfd op dit gebied kleur te bekennen en er een aparte tentoonstelling en monografie aan te besteden. ${ }^{3}$ Het Hong Kong Museum heeft daarmee een lans gebroken voor de waardering van kopieën van Chinees porselein als onderdeel van de huidige Chinese kunst. De makers ervan zijn in het volle voetlicht getreden, uit de duisternis die de eindeloze schare van porseleinmakers omhulde, die volgens traditie tot op heden hun productie leverden maar volledig anoniem bleven.

Waar dit boek voornamelijk ingaat op de decoratie van porselein, vormt het een waardevolle aanvulling op het in 2002 verschenen The traditional crafts of porcelain making in Jingdezhen, dat voornamelijk ingaat op alle overige technieken voor de vervaardiging van porselein in Jingdezhen, maar waarin dit deel van de techniek goeddeels ondergewaardeerd bleef. ${ }^{4}$ Het is verheugend dat de wereld dankzij dergelijke bronnen meer en meer kan leren over de technieken die in het huidige China leiden tot onvergelijkbaar rijke kunstwerken die evenwaardig zijn aan hun voorbeelden uit het verleden.

- (Joan) Ho Yi Hsing (red.)

Traditional Jingdezhen wares from contemporary kilns

Hongkong 2009

210 pagina's, gebonden, rijk geïlustreerd met kleurenfoto's

ISBN978-962-8038-88-6

\section{Noten}

1. Overigens valt zelfs vaak te twijfelen aan porselein dat in niet-academische Chinese bronnen wordt behandeld zoals bijvoorbeeld het Chenghua-porselein in het boek van Ho Wing Meng, The Emperor's lost treasure/ remnants of unrecorded Chenghua porcelain, Singapore, 2003.

2. H. Borel, Het schone eiland, Amsterdam, 1922 ( $2^{\mathrm{e}}$ druk), p. 93.

3. Museum Princessehof te Leeuwarden heeft enkele jaren geleden als eerste museum in Nederland bewust voorbeelden van moderne imitaties van Chinees porselein in haar collectie opgenomen.

4. Bai Ming, The traditional crafts of porcelain making in Jingdezhen, Jiangxi, 2002. 